Original article

\title{
REPRESENTATIVE \\ BUREAUCRACY, IMMIGRANTS, AND TRUST IN GOVERNMENT: A CROSS-NATIONAL STUDY
}

Jesse W. Campbell

Department of Public Administration Incheon National University. Address: 119 Academy-ro, Songdo 1-dong, Yeonsu-gu, Incheon, South Korea, 22012 E-mail: jcampbell@inu.ac.kr

Abstract. Building a civil service that reflects the diversity of the population it serves can increase bureaucratic legitimacy and the fairness of public service provision. In this study, I draw on symbolic representation theory and argue that the impact of representative bureaucracy on trust in government can vary by citizen immigration status. Combining microlevel demographic and opinion data from respondents in 43 countries and country-level estimates of the representativeness of government personnel, I implement a series of multi-level models to test the theory. The analysis suggests that the representativeness of government bureaucracy does not affect trust in the average case but is a significant factor for first generation immigrants. This study provides new evidence for the trust-enhancing effect of representative bureaucracy among minority stakeholders. I discuss how a cross-national approach can further enrich the theoretical landscape of the representative bureaucracy construct.

Keywords: representative bureaucracy, immigration, trust in government, comparative public administration.

Funding: This work was supported by an Incheon National University Research Grant in 2020.

For citation: Campbell, J.W. (2021) 'Representative bureaucracy, immigrants, and trust in government: A cross-national study', Public Administration Issues, 6 (Special Issue II, electronic edition), pp. 7-23 (in English). DOI: 10.17323/1999-5431-2021-0-6-7-23. 


\section{Introduction}

A government that fails to produce the public services desired by its citizens is unlikely to enjoy their trust. However, while public service quality and trust in government are undoubtedly related, one is not necessarily a linear function of the other (Van de Walle and Bouckaert, 2007). Citizens differ in their experiences and knowledge of government, and, while it is possible to estimate the average quality of public service provision for a given population, factors at the individual level, such as gender, ethnicity, or socio-economic status, may affect the actual quality of public services produced and received (Pedersen, Stritch, and Thuesen, 2018). Citizens have different values and preferences, and aggregate models of trust can distort the factors driving trust (or distrust) for certain groups (Wilkes, 2015). Consequently, there is a need to understand how different citizen attributes, experiences, and life histories determine the criteria by which government is judged and ultimately its perceived trustworthiness.

Empirical research has demonstrated that ethnicity and race are related to trust in different ways and in different countries (Marschall and Shah, 2007; Maxwell, 2010a; Leigh, 2006; Wilkes, 2015), and immigrants can have different views about government compared to native-born citizens due to their alternative evaluative reference points, different life experiences, and exposure to different policies (Dahlberg and Linde, 2018; Maxwell, 2010a; Nichols, LeBron and Pedraza, 2018; Rijavec and Pevcin, 2018). When immigrants do not fall into the dominant ethnic, linguistic, or religious categories of their new homes, they may face difficulties integrating into mainstream society. However, if trust in government is associated with heightened intentions to engage with available public policy and programs, it may be useful to know which factors are of particular significance for this group of stakeholders.

The concept of representative bureaucracy is relevant to this case. In brief, a bureaucracy is representative when the composition of its personnel reflects the structural diversity of the society it serves (Bradbury and Kellough, 2011). While earlier work on representative bureaucracy assumed that its positive effect for minorities would be realized through the advocacy of minority government employees, an emerging stream of theory and research known as symbolic representation suggests that greater diversity in the public workforce can heighten the trust of minorities and less advantaged citizens, in turn increasing their willingness to cooperate with government and coproduce public services (Riccucci and Van Ryzin, 2016; Riccucci and Van Ryzin, 2017). The proposed link between trust and representative bureaucracy makes the symbolic representation perspective a compelling framework with which to study the relationships proposed in this study.

Until now, most of the research on both trust in government and representative bureaucracy has been carried out in the United States or other Western countries, and a recent review of the representative bureaucracy literature noted its geographic concentration and called for research to be conducted in different contexts (Bishu and Kennedy, 2020). Importantly, the assumptions that underlie both trust in government and representative bureaucra- 
cy are not context specific, and it is reasonable to assess their validity using a cross-national research design. To this end, I use individual-level data across 34 countries from the World Values Survey (Wave 6, Inglehart et al., 2014) and a unique measure of representative bureaucracy at the national level obtained from the Quality of Government Institute (Dahlström et al., 2015a) to test whether a bureaucracy that is representative of the citizenry can impact levels of trust in government for immigrants as well as the children of immigrants. Before describing the parameters of the test, I first lay out the theoretical position that motivates it. Following a presentation of the empirical analysis and results, I discuss the study's implications and limitations, and suggest that a cross-national approach can further enrich the theoretical landscape of the representative bureaucracy construct

\section{Literature}

\section{Representative bureaucracy}

A bureaucracy is representative to the extent that the demographic characteristics of its employees reflect those of the constituents that it serves (Bishu and Kennedy, 2019). Passive representativeness, or achieving a sufficient level of compositional reflectivity, may be seen as a marker of a government's success in addressing deficits in social equity, reducing discriminatory hiring practices, and infusing democratic values into personnel management (Riccucci and Van Ryzin, 2017). From the perspective of social justice, representative bureaucracy may be understood as a moral imperative and a condition of fairness.

In addition to the normative argument for representative bureaucracy, some studies have sought to understand the extent to which it also has instrumental value. If having a passively representative bureaucracy translates into concrete benefits for women, minorities, and less advantaged citizens more generally, then representativeness is both normatively and instrumentally desirable. The theoretical model underlying the instrumentality hypothesis predicts that social origins are associated with specific values and preferences that in turn shape the actions of bureaucrats, encouraging understanding, responsiveness, and additional care for those with similar origins (Riccucci and Meyers, 2004; Saltzstein, 1979). Although there are presumably many factors at the managerial level as well as in the process of public service (co-)production itself that condition the impact of representative bureaucracy (Meier, 2019), the active representation hypothesis has found some support in the empirical literature. Impressively, the theory has been applied in diverse areas including the awarding of government contracts to minority-owned enterprises (Brunjes and Kellough, 2018; Fernandez, Malatesta and Smith, 2013; Smith and Fernandez, 2010), women's employment, career achievement, and security in the workplace (Choi, Hong and Lee, 2018; Guul, 2018; Rabovsky and Lee, 2018), academic achievement for women and minorities (Atkins, Fertig and Wilkins, 2014; Capers, 2018; Egalite and Kisida, 2018; Favero and Molina, 2018; Nicholson-Crotty et al., 2016; Song, 2018; Vinopal, 2018), and policing outcomes for both women (Schuck 2018) and minorities (Hong, 2016; 
Hong, 2017a; Hong, 2017b; Nicholson-Crotty, Nicholson-Crotty and Fernandez, 2017), as well as organizational performance more generally (Fernandez, Koma and Lee, 2018; Fernandez and Lee, 2016; Lee, 2019).

The arguments in the passive representativeness literature have led to a strengthening of the normative imperative to diversify public bureaucracies. Evidence from the active representativeness literature has furnished an instrumental motivation as a supplement to this normative core. However, a third theoretical approach to representative bureaucracy, known as symbolic representation (Bishu and Kennedy, 2019), has emerged. This approach focuses on the perception of government by citizens, suggesting that, in addition to the active channel of improved policy outcomes, performance gains may result from enhanced cooperation and a willingness to coproduce public goods. From a symbolic representation perspective, representative bureaucracy benefits citizens not necessarily because ethnic minorities within the bureaucracy perform an activist role, but rather because a representative bureaucracy will increase citizen (and minority) trust in government, and, in turn, heighten citizen cooperation with government officials and compliance with public policy (Riccuci and Van Ryzin, 2017; Riccucci, Van Ryzin and Li, 2016). The operative mechanism is thus similar to that of active representation but runs in the opposite direction: women, minorities, or less advantaged citizens may more readily identify with government officials who reflect their own life histories and circumstances and thereby be more willing to trust them.

Research on the symbolic channel between representative bureaucracy and public policy outcomes is not as developed as that of the passive and active literatures. However, recent empirical studies suggest the efficacy of this path. For instance, Riccucci, Van Ryzin, and Li (2016) show that when women are visibly represented in an agency responsible for recycling, female constituents report a greater willingness to participate in recycling programs (however, see Sievery (2021), which fails to reproduce this result). Roch, Elsayed and Edwards (2018) demonstrate that the perceived fairness and legitimacy of disciplinary actions taken against students is greater to the extent that schools have a higher level of passive representation. In a conceptually related study, Riccucci, Van Ryzin, and Jackson (2018) show that perceptions of police fairness and trust among black citizens increases with black representativeness in the police force. This study is related to the earlier work of Theobald and Haider-Markel (2009), who showed that black citizens perceive police action to be more legitimate when the majority of officers are black (they showed also that the same is true for white citizens evaluating a predominantly white police force). In another instance, Gade and Wilkins (2013) demonstrate that veterans enrolled in a vocational rehabilitation program report higher levels of satisfaction and other relevant attitudes when they believed that their counselor was also a veteran.

These empirical studies provide an evidential basis for the symbolic representation hypothesis. However, like many areas of study in public administration, empirical research has been carried out primarily in the American and European context. This geographic research concentration overlooks the vari- 
ous ways in which Western society and government may differ in systematic ways from developing countries or countries with different cultural traditions. However, as the theoretical assumptions of the relationship between representative bureaucracy and ethnic and racial minority effects are not culturally or geographically specific, it is reasonable to test whether the relationship holds across a broader range of contexts.

\section{Immigrants, trust in government, and representative bureaucracy}

Successfully integrating immigrants, who are often ethnic or linguistic minorities, into mainstream society can be a policy challenge. While local communities can play a role in the integration process, a lack of trust on the part of immigrants of central government institutions may undermine the implementation of integration policy and programs. The difference between how immigrants see government may also differ between generations. Maxwell (2010a) demonstrates that first-generation immigrants tend on average to have more positive views of government than native-born citizens. However, this difference reduces in size or disappears for second generation immigrants that have been raised in the country and therefore exposed to similar socialization processes from birth. On the other hand, Maxwell (2010b, p. 46) notes that even second-generation immigrants often continue to suffer from "stigmatization and discrimination," failing to achieve full integration into their country while at the same time not feeling completely part of their homeland origins. Immigrants can face barriers to integration including frustrated aspirations for upward social mobility (particularly for low-skill immigrants), racial and ethnic discrimination (particularly for immigrants of non-European origins in Western societies), and, for immigrants arriving from countries with higher levels of political repression, difficulties adapting to the norms of democratic societies (Maxwell, 2010a). On the other hand, this contrasting background can also be a source of increased positive attitudes about the host country (Maxwell, 2010b).

In this study, I test whether representative bureaucracy affects immigrants and non-immigrants differentially. Based on prior empirical research and drawing on the symbolic representation perspective, I propose the following hypothesis:

Hypothesis 1: Immigrant status positively moderates the relationship between representative bureaucracy and trust in government.

Given that the literature has pointed out subtle differences in the integration experiences of second and first generation immigrants (Abouguendia and Noels, 2001; Maxwell, 2010a; 2010b) but does not suggest that representative bureaucracy would affect the two groups differently, I also test the following two hypotheses:

Hypotheses $2 \mathrm{a}$ and $2 \mathrm{~b}$ : Second generation immigrant status (2a) and first generation immigrant status (2b) positively moderate the relationship between representative bureaucracy and trust in government.

The next section describes the data and empirical methods I use to implement the model. 


\section{Data and methods}

\section{Dependent variable: Trust in government}

To measure the dependent variable as well as all other individual-level variables in the analysis, I use data from Wave 6 of the World Values Survey (Inglehart et al., 2014). As the name suggests, the World Values Survey polls individuals across a diverse selection of countries about their perspectives on topics of socio-economic importance. To measure trust in government, I use questions that ask respondents to rate on a scale of 1 to 4 how much confidence they have in various public institutions. A selection of these variables has commonly been used to measure diffuse political trust or trust in government (see Breustedt (2018) and Tao (2021) for a review). I use the mean of confidence in the police, courts, the government in the nation's capital, political parties, parliament, and the civil service. Although these are different aspects of government, a factor analysis suggests that the combined scale is one-dimensional. The internal consistency of the questions is a high .87. However, based on the possibility that trust in specifically administrative organizations may have different foundations than more broadly political ones (Camões and Mendes, 2019), I also use a reduced 2-item scale capturing trust only in the government and civil service. This second measurement is correlated with the 6 -item scale at $.90(\mathrm{p}<.001)$ but has a lower alpha value of 67 .

\section{Independent variable: Representative bureaucracy}

Representative bureaucracy captures the extent to which the diversity of the public service reflects the diversity of society (Riccucci and Van Ryzin, 2017). Scholars have measured this variously (Bradbury and Kellough, 2020), but many of these measures have been sub-national and cannot be used in a cross-national analysis. In this study, I use data from the Quality of Government (QoG) Institute's Expert Survey II (Dahlström et al., 2015) to measure representative bureaucracy. The QoG Expert Survey II dataset provides quantitative estimates of structural characteristics of national bureaucracies averaged from the survey responses of international public administration experts. The data has been used in a variety of studies to measure concepts such as merit-based recruitment and tenure protections (Nistoskaya and Cingolani, 2016), performance pay usage (Campbell, 2020a), and national auditing capacity (Gustavson and Sundstrom, 2018). To measure representative bureaucracy, I use responses to the following statement: "Key ethnic and religious groups in society are proportionally represented among public sector employees." Although the estimate is based on a subjective evaluation and not raw personnel data, the question has a high degree of face validity for the construct and captures the core ideas of representation and proportionality in the civil service. The scale runs from 1 (hardly ever) to 7 (almost always), and thus higher values on the scale represent higher levels of representative bureaucracy.

Figure 1 shows the level of representative bureaucracy plotted against country-level mean estimates of trust in government. Although both trust and representative bureaucracy have considerable levels of variation in the data, they are not correlated at statistically significant levels. 


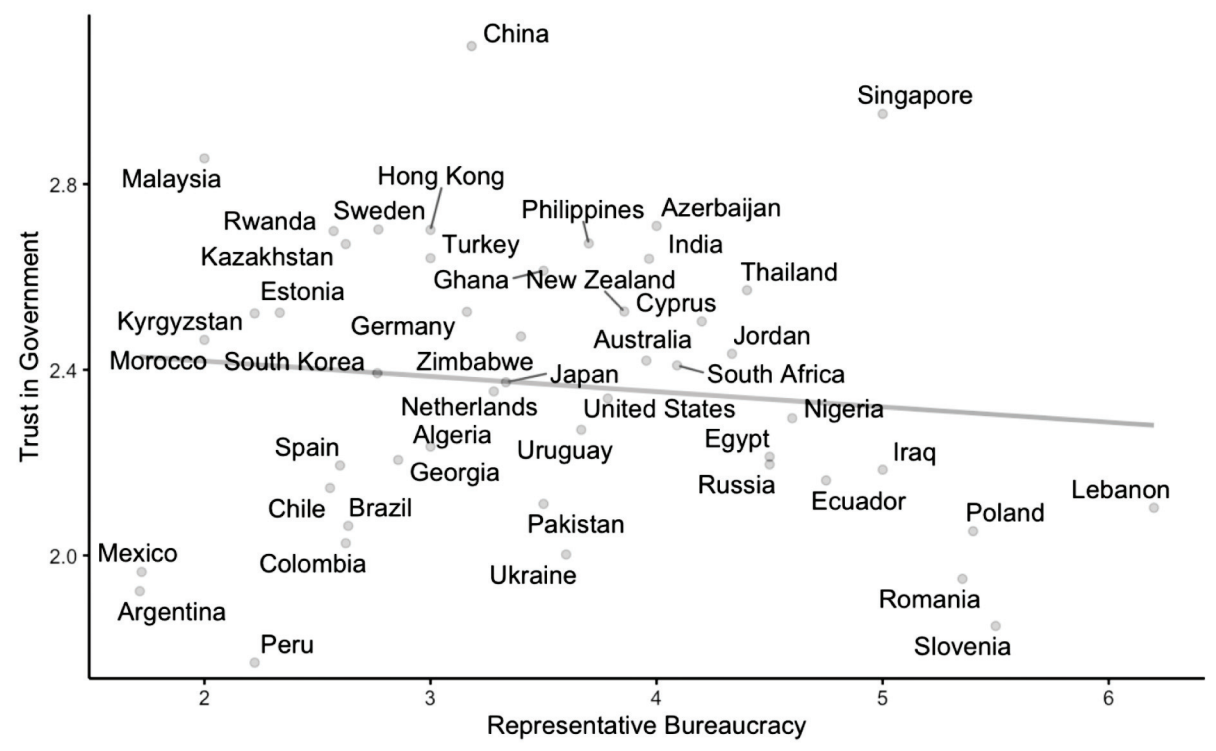

Figure 1: Representative bureaucracy by trust in government.

\section{Independent variable: Immigration status}

I follow Maxwell (2010a) and Röder and Mühlau (2012) and create three categories of respondents to capture immigration status. Country-native respondents are those who are neither themselves immigrants nor have immigrant parents. Second-generation immigrants are those who are themselves not immigrants but have at least one parent that is. Finally, first generation immigrants are those that have themselves immigrated to their country of residence.

Figure 2 shows the percentage of immigrants in the sample countries (inclusive of both first and second generation immigrants). Jordan, New Zealand, and Singapore have the highest percentage of their sample made up of immigrants. In contrast, Morocco, the Philippines, and Egypt had the fewest, each with less than 1 percent of their sample reporting to be either first or second generation immigrants. I note here that these sample proportions are correlated at .76 $(p<.001)$ with the World Bank's estimates of international migrant population percentages (World Bank, 2016).

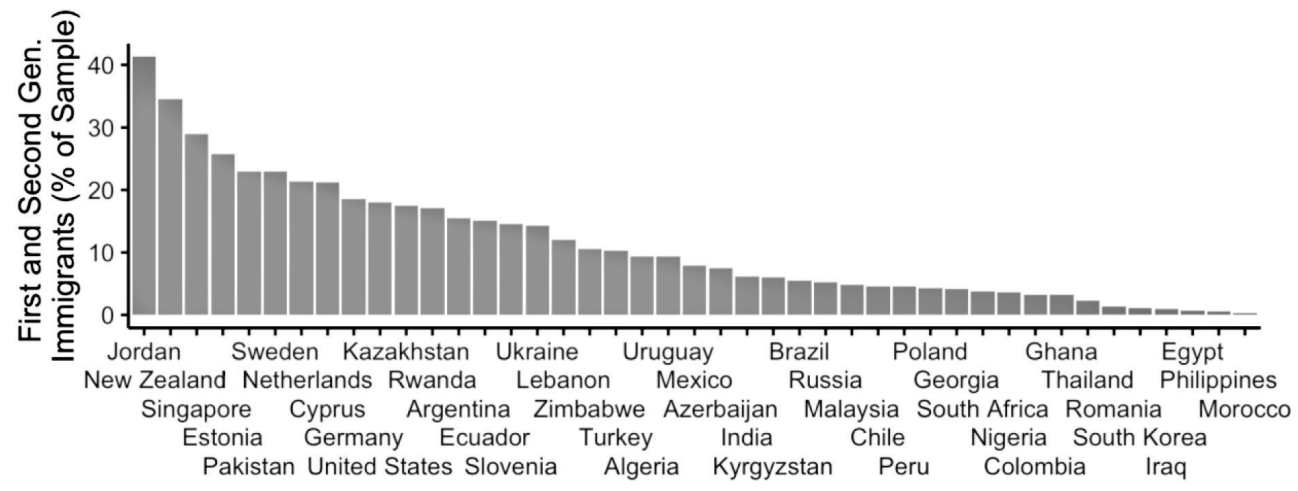

Figure 2: Immigrants in the sample countries (inclusive of both first and second generation immigrants), $\%$. 


\section{Control variables}

At the individual level, I control for respondent sex, age, and level of education. I also control for social trust using a dummy variable coded 1 for respondents who answered "Most people can be trusted" when dealing with others and 0 for those who answered "Need to be very careful" (Camões and Mendes, 2019). I further control for three significant factors at the country level. Citizens of more developed countries may have higher levels of trust in their government, and development is also closely related to public service quality. I therefore control for economic development by including a measure of GDP per capita (log) from the World Bank's Development Indicators (2016). How positions linked with political power are distributed may also affect trust in government. I thus add a control for levels of democracy using Freedom House's iPolity measure for the year 2014 (2019). To better isolate the composition of government from its performance, I control for two additional factors. First, Fund for Peace's estimate of public service quality from the Fragile States Index (Messner et al., 2015) captures public service performance across a range of vital services. Finally, I also include an estimate of Control of Corruption from the World Bank's Governance Indicators from 2014 (Kaufmann et al., 2010).

Table 1 shows descriptive statistics for the variables used in this study.

Table 1

Descriptive statistics

\begin{tabular}{lcccc}
\hline Variable & Mean & SD & Min & Max \\
\hline Individual level & & & & \\
$\quad$ Trust in Government & 2.37 & 0.72 & 1 & 4 \\
Non-immigrant & 0.89 & 0.31 & 0 & 1 \\
$\quad$ First Gen. Immigrant & 0.04 & 0.20 & 0 & 1 \\
Second Gen. Immigrant & 0.06 & 0.25 & 0 & 1 \\
Female & 0.51 & 0.50 & 0 & 1 \\
Age & 41.74 & 16.48 & 16 & 102 \\
Education & 5.70 & 2.38 & 1 & 9 \\
Social Trust & 0.25 & 0.43 & 0 & 1 \\
Country level & & & & \\
Representative Bureaucracy & 3.52 & 1.00 & 1.7 & 6.2 \\
GDP per Capita (log) & 9.52 & 0.93 & 7.4 & 11.3 \\
Democracy & 6.74 & 2.91 & 0.25 & 10 \\
Public Service Quality & 5.89 & 2.17 & 1.9 & 9.5 \\
Control of Corruption & 2.51 & 1.07 & 0.9 & 4.8 \\
\hline
\end{tabular}

Sources: Author's calculations based on various datasets.

\section{Results}

Because individual responses are nested in countries, I specify the model using a multilevel estimator (Hox, Moerbeek and Van de Schoot, 2017), including random intercepts and slopes for the immigrant status variables. The interclass 
correlation coefficient suggests that about $22 \%$ of the variance in trust in government is explained by country context, which implies that a multilevel estimation approach is appropriate.

Table 2

\section{Trust in government, representative bureaucracy, and immigrant status}

\begin{tabular}{|c|c|c|c|c|c|c|c|c|c|}
\hline Variable & Model 1 & Model 2 & Model 3 & Model 4 & Model 5 & Model 6 & Model 7 & Model 8 & Model 9 \\
\hline Representative Bureaucracy & -0.01 & -0.01 & -0.03 & -0.02 & -0.02 & -0.02 & -0.03 & -0.01 & -0.01 \\
\hline Immigrant (1st or 2nd Gen) & & -0.02 & -0.01 & -0.02 & -0.02 & & & & \\
\hline Representative Bureaucracy $\times$ Immigrant & & & $0.04^{*}$ & $0.04^{*}$ & $0.04^{*}$ & & & & \\
\hline Second Gen. Immigrant (SGI) & & & & & & -0.03 & -0.02 & -0.02 & -0.03 \\
\hline First Gen. Immigrant (FGI) & & & & & & -0.02 & -0.02 & -0.02 & -0.02 \\
\hline Representative Bureaucracy x SGI & & & & & & & 0.04 & 0.04 & 0.04 \\
\hline Representative Bureaucracy $\times$ FGI & & & & & & & $0.06^{* *}$ & $0.06^{* * *}$ & $0.06^{* *}$ \\
\hline GDP per Capita (log) & & & & 0.01 & 0.01 & & & 0.00 & -0.01 \\
\hline Democracy & & & & $-0.07^{* * *}$ & $-0.07^{* * * * *}$ & & & $-0.07^{* * * *}$ & $-0.07^{* * * * *}$ \\
\hline Public Service Quality & & & & -0.04 & -0.05 & & & -0.06 & $-0.07^{*}$ \\
\hline Control of Corruption & & & & $0.24^{* * *}$ & $0.24^{* * *}$ & & & $0.27^{* * *}$ & $0.27^{* * *}$ \\
\hline Female Respondent & & & & & $0.02^{* * * 4}$ & & & & $0.02^{* * * * *}$ \\
\hline Age & & & & & $0.00^{* * *}$ & & & & $0.00^{* * *}$ \\
\hline Education & & & & & 0.00 & & & & 0.00 \\
\hline Social Trust & & & & & $0.17^{* * *}$ & & & & $0.17^{* * *}$ \\
\hline Intercept & $2.34^{* * *}$ & $2.35^{* * *}$ & $2.35^{* * *}$ & $2.41^{* * *}$ & $2.37^{* * *}$ & $2.35^{* * *}$ & $2.35^{* * *}$ & $2.51^{* * *}$ & $2.57^{* * *}$ \\
\hline Residual Variance & 0.43 & 0.43 & 0.43 & 0.43 & 0.42 & 0.43 & 0.43 & 0.43 & 0.42 \\
\hline Intercept Variance & 0.08 & 0.08 & 0.08 & 0.05 & 0.05 & 0.08 & 0.08 & 0.05 & 0.05 \\
\hline Slope: Immigrant & 0.01 & 0.01 & 0.01 & 0.01 & 0.01 & & & & \\
\hline Slope: First Gen. Immigrant & & & & & & 0.01 & 0.00 & 0.00 & 0.00 \\
\hline Slope: Second Gen. Immigrant & & & & & & 0.02 & 0.02 & 0.02 & 0.02 \\
\hline Countries & 43 & 43 & 43 & 43 & 43 & 43 & 43 & 43 & 43 \\
\hline Observations & 59,307 & 59,307 & 59,307 & 59,307 & 58,030 & 59,307 & 59,307 & 59,307 & 58,030 \\
\hline
\end{tabular}

Sources: Author's calculations based on various datasets.

Model 1 contains only representative bureaucracy as a predictor of trust in government. Model 2 adds the first immigration variable. Independently, neither of these factors appears to be a significant predictor of trust in government. Model 3 adds an interaction term, which is positive and statistically significant. In line with the general orientation of this study, this suggests that the effect of representative bureaucracy on trust is potentially significant for immigrants. Models 4 and 5 add country and individual level control variables, respectively. In Model 4 , we can see a negative and statistically significant correlation between democracy and trust in government. This is consistent with some of the empirical political science research (You and Wang, 2020). The results also suggest that controlling corruption has a positive relationship with citizen trust, a result that is, again, consistent with prior research (Catterberg and Moreno, 2005). Model 5 suggests that female respondents and older respondents tend to trust government more. Unsurprisingly, social trust is positively related to trust in government. 
Models 6 through 9 are similar to Models 2 through 5 but disaggregate immigrant status into first and second generation and thereby address hypotheses $2 \mathrm{a}$ and $2 \mathrm{~b}$. While neither of the disaggregated immigrant status variables are independently significant predictors of trust, the interaction effect between first generation immigrant status and representative bureaucracy is positive and statistically significant across all models. In contrast, there is no significant interaction with representative bureaucracy and second generation immigrant status, suggesting that the effect is limited to those who are themselves immigrants but not the children of immigrants.

To better interpret this effect, I graph trust in government as a joint function of representative bureaucracy and first generation immigrant status. Figure 3 shows the interaction effect. Representative bureaucracy has a positive relationship with trust in government for first generation immigrants. For those not in this citizenship category, the relationship appears to lack significance. This effect is consistent with hypothesis $2 \mathrm{~b}$ of this study.

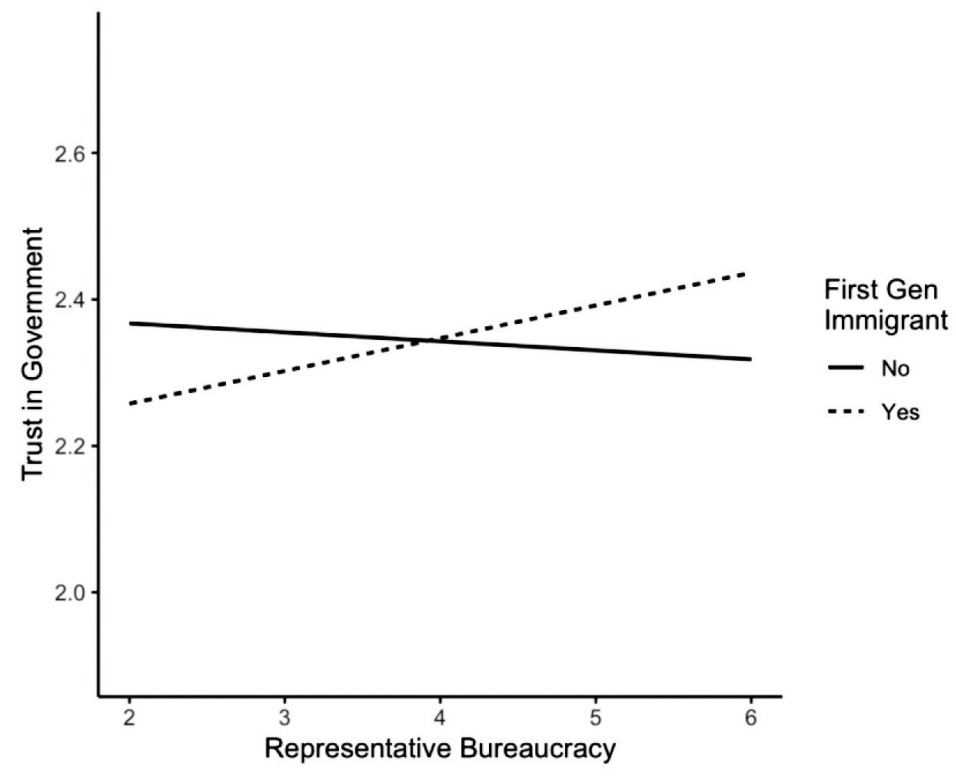

Figure 3: Moderating effect of immigration status on the relationship between representative bureaucracy and trust in government.

\section{Discussion}

This study takes a novel cross-national approach to the study of representative bureaucracy and links the construct to trust in government among immigrants. The key finding is that representative bureaucracy is positively related to trust in government for (first generation) immigrants, which is consistent with the symbolic theory of bureaucratic representation described by Riccucci et al. (2014) and others. This finding has implications for the theory of representative bureaucracy and is suggestive of further research paths. 
I note some limitations of this study and suggest ways that future work can improve upon and extend the findings. First of all, even though this is, to the author's knowledge, the first study to conduct a cross-national, multi-level analysis of representative bureaucracy, and the sample of countries included in the analysis represents a range of situations, a survey-based measure of representative bureaucracy rather than one based in numerical personnel data was used. This measure has both strengths and weaknesses. In terms of the former, the general nature of the survey question allows for comparability between countries. Moreover, numerous validity checks conducted by the stewards of the Expert II survey suggest that the data itself is of a high quality, with marginal bias due to characteristics of the expert panel (Dahlström et al., 2015b). This being said, a generic surveybased approach cannot capture the full range of experiences between countries. For instance, the measure is a country-level measure capturing representative bureaucracy in the central government as a whole. In reality, there likely would be variations not only in how representative bureaucracy is implemented between countries that this survey measure fails to capture, but also within government (for instance, between high-ranking and front-line staff, or between different regions) there are likely to be differences. Although capturing these differences empirically may mean restricting sample size, this nevertheless would help bring out the nuances of the studied relationships.

Second, I note that the measure of immigrant status I use is quite crude. Although the variable clearly captures first and second generation immigration status, it says little about the degree to which the given respondent is distinct in various ways from the host country population. Relevant differences may be ethnicity, language spoken, religion, or cultural traditions. Others have used more finegrained estimates which capture length of residency as well as the level of relative cultural and other differences between the host and migrant country. For instance, Röder and Mühlau (2012) attribute to origin country frames of references the high level of trust on first generation immigrants. Immigration status does not capture this level of complexity and subtlety in the actual situations of respondents. Integrating these factors into an empirical model may provide further clarity about the impact of representative bureaucracy on trust for immigrants and minorities.

Next, I note again that representative bureaucracy has no statistically significant direct effect on trust in government, even before controlling for alternative explanatory factors. However, trust in government is not the only outcome relevant to the representative bureaucracy concept and was selected as a dependent variable in this study to test the symbolic representation theory of representative bureaucracy. Importantly, prior research has demonstrated that representative bureaucracy can lead to positive, concrete outcomes for individuals (Bishu and Kennedy, 2020; Kennedy, 2014), which this study does not test. Although trust in government is important from the perspective of securing compliance and may lead to enhanced coproduction among minority classes of citizen (Riccucci et al., 2017), and moreover may be thought of as a normative imperative, linking up representative bureaucracy with actual service quality and other outcomes of interest rather than subjective evaluations of government trustworthiness is an important research goal which this study's results should not dissuade re- 
searchers from pursuing. Of course, although the symbolic representation perspective represents an important contribution to the theory of representative bureaucracy, scholars continue to be concerned about how bureaucracy actually impacts citizens and the conditions under which representativeness is likely to improve bureaucratic outcomes, with bureaucrats directly acting in the interests of clients (Meier, 2019).

Much of the research on representative bureaucracy has been conducted in a single country, which in turn necessitates a focus on the individual-level factors, for instance, whether or not the gender/race of the public service provider and client match (Riccucci et al., 2016; Riccucci et al., 2018). However, studying representative bureaucracy in a cross-national context allows isolating factors that single-context studies preclude. One research path may link up levels of ethnic homogeneity with administrative traditions and test their joint influence in determining the impact of representative bureaucracy. For instance, both Singapore and South Korea have a strong state tradition and high levels of public service quality (Im, Campbell and Cha, 2013; Kasdan and Campbell, 2020; Wade, 2018). However, the former is very diverse whereas the latter has one of the most homogenous populations in the world. Studying the character, conditions, and impact of representative bureaucracy in such contexts in a comparative manner may produce additional insights beyond what can be achieved by focusing exclusively on rich Western countries. Or, ethnolinguistic fractionalization is linked with low growth (Posner, 2004), partly as fractionalization provides incentives to use individual connections in the recruitment process of government at the expense of merit (Sundell, 2014). The interplay between context, recruitment, representativeness, and performance deserves careful treatment as it can shed further light on the relevance of representative bureaucracy to government performance.

Another area of research with which the symbolic perspective on representative bureaucracy may intersect is that of organizational communication and public relations. Communication and the provision of information matters for trust, both within government and for citizens (Campbell and Im, 2015; Im and Campbell, 2020; Van de Walle and Bouckaert, 2003; Yang and Holzer, 2006), particularly as government performance is a complex construct that may not be readily accessible to citizens accustomed to drawing upon a private sector-derived performance model (Campbell, 2020b). In the current study, I argued that representative bureaucracy would have a larger impact on trust in government for immigrants based on the symbolic representation approach. However, one assumption of this argument is that citizens actually pay attention to the composition of government, an assumption that is absent from the active representation approach, which is based in concrete action and the interaction between government and citizens. The composition of government is in many cases largely hidden from citizens, particularly for organs that have an administrative or internal focus. The relative visibility of representative bureaucracy to the citizen should thus be a core determinant of its symbolic impact, and researchers may explore how different ways of making the representativeness of government salient for citizens shapes its impact on trust and other outcomes of interest. 
By providing a cross-national, multi-level test of the relationship between representative bureaucracy and trust in government for immigrants, this study provides new evidence for the symbolic representation hypothesis. Although there are limitations and questions remain, this study makes a contribution by leveraging novel data to bring empirical evidence to bear on the link between representative bureaucracy and perceptions of government. As global migration continues to accelerate, and with many (particularly in developing countries) continuing to suffer from poor government and diminished life chances, facilitating an understanding of how public administration can better serve a diverse set of constituents is a practical imperative of growing urgency.

\section{REFERENCES}

Abouguendia, M. and Noels, K. A. (2001) 'General and acculturation-related daily hassles and psychological adjustment in first- and second-generation South Asian immigrants to Canada', International Journal of Psychology: Journal International de Psychologie, 36(3), pp. 163-173.

Atkins, D.N., Fertig, A.R. and Wilkins, V.M. (2014) 'Connectedness and expectations: How minority teachers can improve educational outcomes for minority students', Public Management Review, 16(4), pp. 503-526.

Bishu, S.G. and Kennedy, A.R. (2020) 'Trends and gaps: A meta-review of representative bureaucracy', Review of Public Personnel Administration, 40(4), pp. 559-588.

Bradbury, M. and Kellough, J.E. (2011) 'Representative bureaucracy: Assessing the evidence on active representation', American Review of Public Administration, 41(2), pp. 157-167.

Breustedt, W. (2018) 'Testing the measurement invariance of political trust across the globe. A multiple group confirmatory factor analysis', Methods Data Analyses, 12(1), pp. 7-45.

Brunjes, B.M. and Kellough, J.E. (2018) 'Representative bureaucracy and government contracting: A further examination of evidence from federal agencies', Journal of Public Administration Research and Theory, 28(4), pp. 519-534.

Camões, P. J. and Mendes, S. M. (2019) 'Do citizens trust the civil service differently? Comparing the determinants of confidence in political-administrative institutions', International Journal of Public Administration, 42(14), pp. 1234-1244.

Campbell, J.W. (2020a) 'Red Tape, rule burden, and legitimate performance trade-offs: Results from a vignette experiment', Public Performance and Management Review, 43(4), pp. 741-765.

Campbell, J. W. (2020b) 'Buying the honor of thieves? Performance pay, political patronage, and corruption' International Journal of Law, Crime and Justice, 63, p. 100439.

Campbell, J.W. and Im, T. (2015) 'Identification and trust in public organizations: a communicative approach’ Public Management Review, 17(8), pp. 1065-1084. 
Capers, K.J. (2018) 'The effect of the external environment on bureaucratic representation: Assessing the passive to active representation link', American Review of Public Administration, 48(4), pp. 301-317.

Catterberg, G. and Moreno, A. (2005) 'The individual bases of political trust: Trends in new and established democracies', International Journal of Public Opinion Research, 18(1), pp. 31-48.

Choi, H., Hong, S. and Lee, J.W. (2018) 'Does increasing gender representativeness and diversity improve organizational integrity?' Public Personnel Management, 47(1), pp. 73-92.

Dahlberg, S. and Linde, J. (2018) 'Socialization or experience? Institutional trust and satisfaction with democracy among emigrants in different institutional settings', The Journal of Politics, 80(4), pp. 1389-1393.

Dahlström, C., Teorell, J., Dahlberg, S., Hartmann, F. and Lindberg, A. (2015) The QoG expert survey II report. University of Gothenburg: The Quality of Government Institute. Available at: https://gupea.ub.gu.se/handle/2077/39869 (Downloaded: 18 July 2021).

Dahlström, C., Teorell, J., Dahlberg, S., Hartmann, F., Lindberg, A. and Nistotskaya, M. (2015) The QoG expert survey dataset II [Data set]. University of Gothenburg: The Quality of Government Institute. Available at: https:/qog.pol.gu.se/data/datadownloads/ qogexpertsurveydata (Downloaded: 18 July 2021).

Egalite, A.J. and Kisida, B. (2018) 'The effects of teacher match on students academic perceptions and attitudes', Educational Evaluation and Policy Analysis, 40(1), pp. 59-81.

Favero, N. and Molina, A.L. (2018) 'Is active representation an organizational-level process? The indirect effect of bureaucrats on clients they don't directly serve', American Review of Public Administration, 48(1), pp. 3-17.

Fernandez, S., Koma, S. and Lee, H. (2018) 'Establishing the link between representative bureaucracy and performance: The South African case'. Governance, 31(3), pp. 535-553.

Fernandez, S. and Lee, H. (2016) 'The transformation of the South African public service: Exploring the impact of racial and gender representation on organisational effectiveness', The Journal of Modern African Studies, 54(1), pp. 91-116.

Fernandez, S., Malatesta, D. and Smith, C.R. (2013) 'Race, gender, and government contracting: Different explanations or new prospects for theory?', Public Administration Review, 73(1), pp. 109-120.

Freedom House (2019) Freedom in the World 2018 [Data set]. Available at: https:// freedomhouse.org/report/freedom-world (accessed 18 July 2021).

Gade, D.M. and Wilkins, V.M. (2013) 'Where did you serve? Veteran identity, representative bureaucracy, and vocational rehabilitation', Journal of Public Administration Research and Theory, 23(2), pp. 267-288.

Gustavson, M. and Sundström, A. (2016) 'Organizing the audit society: Does good auditing generate less public sector corruption?', Administration and Society, 50(10), pp. 1508-1532.

Guul, T.S. (2018) 'The individual-level effect of gender matching in representative bureaucracy', Public Administration Review, 78(3), pp. 398-408. 
Hong, S. (2016) 'Representative bureaucracy, organizational integrity, and citizen coproduction: Does an increase in police ethnic representativeness reduce crime?', Journal of Policy Analysis and Management, 35(1), pp. 11-33.

Hong, S. (2017a) 'Does increasing ethnic representativeness reduce police misconduct?', Public Administration Review, 77(2), pp. 195-205.

Hong, S. (2017b) 'Black in blue: Racial profiling and representative bureaucracy in policing revisited', Journal of Public Administration Research and Theory, 27(4), pp. 547-561.

Hox, J.J., van de Schoot, R. and Moerbeek, M. (2017) Multilevel analysis: Techniques and applications (3rd Edition). Routledge: New York, NY.

Im, T. and Campbell, J.W. (2020) 'Coordination, incentives, and persuasion: South Korea's comprehensive approach to COVID-19 containment', Korean Journal of Policy Studies, 35(3), pp. 119-139.

Im, T., Campbell, J.W. and Cha, S. (2013) 'Revisiting Confucian bureaucracy: Roots of the Korean government's culture and competitiveness', Public Administration and Development, 33(4), pp. 286-296.

Inglehart, R., Haerpfer, C., Moreno A. et al. (2014) World values survey: Round six - country-pooled datafile 2010-2014 [Data set]. Available at: http://www.worldvaluessurvey.org/ WVSDocumentationWV6.jsp (accessed 18 July 2021).

Kasdan, D.O. and Campbell, J.W. (2020) 'Dataveillant collectivism and the Coronavirus in Korea: Values, biases, and socio-cultural foundations of containment efforts', Administrative Theory and Practice, 42(4), pp. 604-613.

Kaufmann, D., Kraay, A. and Mastruzzi, M. (2010) 'The worldwide governance indicators: A summary of methodology', Data and Analytical Issues, World Bank Policy Research Working Paper, 5430.

Kennedy, B. (2014) 'Unraveling representative bureaucracy: A systematic analysis of the literature', Administration and Society, 46(4), pp. 395-421.

Lee, H. (2019) 'Does increasing racial minority representation contribute to overall organizational performance? The role of organizational mission and diversity climate', American Review of Public Administration, 49(4), pp. 454-468.

Leigh, A. (2006) 'Trust, inequality and ethnic heterogeneity', The Economic Record, 82(258), pp. 268-280.

Marschall, M. and Shah, P.R. (2007) 'The attitudinal effects of minority incorporation: Examining the racial dimensions of trust in urban America', Urban Affairs Review, 42(5), pp. 629-658.

Maxwell, R. (2010a) 'Evaluating migrant integration: Political attitudes across generations in Europe’, The International Migration Review, 44(1), pp. 25-52.

Maxwell, R. (2010b) 'Trust in government among British Muslims: The importance of migration status', Political Behavior, 32(1), pp. 89-109.

Meier, K.J. (2019) 'Theoretical frontiers in representative bureaucracy: New directions for research', Perspectives on Public Management and Governance, 2(1), pp. 39-56. 
Messner, J.J., Haken, N., Taft, P., Lawrence, K., Umana, F., Pavlou, S. and Blyth, H. (2015) Fragile States Index 2015 - Annual Report. The Fund for Peace. Available at: https:// fragilestatesindex.org/ (accessed 18 July 2021).

Nichols, V.C., LeBron, A.M.W. and Pedraza, F.I. (2018) 'Spillover effects: Immigrant policing and government skepticism in matters of health for Latinos', Public Administration Review, 78(3), pp. 432-443.

Nicholson-Crotty, S., Grissom, J. A., Nicholson-Crotty, J. and Redding, C. (2016) 'Disentangling the causal mechanisms of representative bureaucracy: Evidence from assignment of students to gifted programs', Journal of Public Administration Research and Theory, 26(4), pp. 745-757.

Nicholson-Crotty, S., Nicholson-Crotty, J. and Fernandez, S. (2017) 'Will more black cops matter? Officer race and police-involved homicides of black citizens', Public Administration Review, 77(2), pp. 206-216.

Nistotskaya, M. and Cingolani, L. (2016) 'Bureaucratic structure, regulatory quality, and entrepreneurship in a comparative perspective: Cross-sectional and panel data evidence', Journal of Public Administration Research and Theory, 26(3), pp. 519-534.

Pedersen, M.J., Stritch, J.M. and Thuesen, F. (2018) 'Punishment on the frontlines of public service delivery: Client ethnicity and caseworker sanctioning decisions in a Scandinavian welfare state', Journal of Public Administration Research and Theory, 28(3), pp. 339-354.

Rabovsky, T. and Lee, H. (2018) 'Exploring the antecedents of the gender pay gap in US higher education', Public Administration Review, 78(3), pp. 375-385.

Riccucci, N.M. and Meyers, M.K. (2004) 'Linking passive and active representation: The case of frontline workers in welfare agencies', Journal of Public Administration Research and Theory, 14(4), pp. 585-597.

Riccucci, N.M. and Van Ryzin, G.G. (2017) 'Representative bureaucracy: A lever to enhance social equity, coproduction, and democracy', Public Administration Review, 77(1), pp. 21-30.

Riccucci, N.M., Van Ryzin, G.G. and Jackson, K. (2018) 'Representative Bureaucracy, Race, and Policing: A Survey Experiment', Journal of Public Administration Research and Theory, 28(4), pp. 506-518.

Riccucci, N.M., Van Ryzin, G.G. and Lavena, C.F. (2014) 'Representative bureaucracy in policing: Does it increase perceived legitimacy?', Journal of Public Administration Research and Theory, 24(3), pp 537-551.

Riccucci, N.M., Van Ryzin, G.G. and Li, H. (2016) 'Representative bureaucracy and the willingness to coproduce: An experimental study', Public Administration Review, 76(1), pp. 121-130.

Rijavec, D. and Pevcin, P. (2018) 'An Examination and Evaluation of Multi-Level Governance During Migration Crisis: The Case of Slovenia', Central European Public Administration Review, 16(1), pp. 81-98.

Roch, C.H., Elsayed, M.A.A. and Edwards, J. (2018) 'Students' and parents' perceptions of disciplinary policy: Does symbolic representation matter?', American Review of Public Administration, 48(4), pp. 329-345. 
Röder, A. and Mühlau, P. (2012) 'Low expectations or different evaluations: What explains immigrants' high levels of trust in host-country institutions?', Journal of Ethnic and Migration Studies, 38(5), pp. 777-792.

Saltzstein, G. (1979) 'Representative bureaucracy and bureaucratic responsibility: Problems and prospects', Administration and Society, 10(4), pp. 465-475.

Schuck, A.M. (2018) 'Women in policing and the response to rape: Representative bureaucracy and organizational change', Feminist Criminology, 13(3), pp. 237-259.

Smith, C.R. and Fernandez, S. (2010) 'Equity in federal contracting: Examining the link between minority representation and federal procurement decisions', Public Administration Review, 70(1), pp. 87-96.

Song, M. (2018) 'Gender representation and student performance: Representative bureaucracy goes to Korea', American Review of Public Administration, 48(4), pp. 346-358.

Sundell, A. (2014) 'Are formal civil service examinations the most meritocratic way to recruit civil servants? Not in all countries', Public Administration, 92(2), pp. 440-457.

Tao, A.K. (2021) Trust, resource efficiency, and new public management: A cross-national mediation analysis. Ed. by J. W. Campbell [Thesis Doctor of Philosophy]. Incheon National University.

The World Bank Washington DC (2016) World Development Indicators [Data set]. In World Development Indicators.

Theobald, N.A. and Haider-Markel, D. P. (2009) 'Race, bureaucracy, and symbolic representation: Interactions between citizens and police', Journal of Public Administration Research and Theory, 19(2), pp. 409-426.

Van de Walle, S. and Bouckaert, G. (2003) 'Public service performance and trust in government: The problem of causality', International Journal of Public Administration, 26(8-9), pp. 891-913.

Van de Walle, S. and Bouckaert, G. (2007) 'Perceptions of productivity and performance in Europe and the United States', International Journal of Public Administration, 30(11), pp. 1123-1140.

Vinopal, K. (2018) 'Understanding individual and organizational level representation: The case of parental involvement in schools', Journal of Public Administration Research and Theory, 28(1), pp. 1-15.

Wade, R.H. (2018) 'The developmental state: Dead or alive?', Development and Change, 49(2), pp. 518-546.

Wilkes, R. (2015) 'We trust in government, just not in yours: Race, partisanship, and political trust, 1958-2012', Social Science Research, 49, pp. 356-371.

Yang, K. and Holzer, M. (2006) 'The performance-trust link: Implications for performance measurement', Public Administration Review, 66(1), pp. 114-126.

You, Y. and Wang, Z. (2020) 'The internet, political trust, and regime types: A cross-national and multilevel analysis', Japanese Journal of Political Science, 21(2), pp. 68-89.

The article was submitted: 20.06.2021; approved after reviewing: 09.07.2021; accepted for publication: 28.11.2021 